\title{
Effectiveness of Cooperative Script Strategy in the Implementation of Character Education
}

\author{
Mohammad Zainuddin ${ }^{1}$ \\ ${ }^{1}$ Universitas Negeri Malang \\ E-mail: 'zainuddinpgsd57@gmail.com
}

Received: 13 October 2017; Revised: 15 October 2017; Accepted: 16 October 2017

\begin{abstract}
Abstrack
Character education and development of Pancasila values need to be implemented in schools to face globalization era that will bring many changes along with acceleration of new cultures and civilizations from various nations in the world. It means the world of education in generating quality of human resources and professionals must prepare a competitive generation of characters. A concrete steps to realize together is character education from an early age. On the other hand, the teacher as the spearhead in education world can insert character implementation in every learning process. One effective step that can be done is to implement cooperative script strategy in learning process and character implementation.
\end{abstract}

Key words: cooperative script strategy, character education

\section{Introduction}

Education in Indonesia is always changing. The change is done in order to improve the quality of education, relevance of education, equity of education and improvement of efficiency and effectiveness of education. Changes in terms of improving the efficiency and effectiveness of education lead to the arrangement of competency-based curriculum and character by giving wide confidence to the school to improve human resources for achievement of expected educational goals. Curriculum 2013 developed as a form of curriculum based on competence and character above, in this case, aspect that is developed is not only focused on the aspects of cognitive (knowledge), but also affective aspects (attitude) and psychomotor (skills).
Through the development of affective aspects contained in the Curriculum 2013 is expected to produce productive and innovative human beings.

One of the goals of education is to prepare the next generation of nation that has competence and can compete in the real world. Competence that is meant is competence in the field of science, skill and social. Social competence is an important thing for every individual because every human being can not be separated from social interaction. Social life in Indonesia is not an easy matter due to our society has a very high diversity. Living in the midst of difference makes it difficult for individuals who are unable to accept and appreciate differences. Every individual in 
society has distinctive characteristics, backgrounds, religions, tribes and different languages. The number of differences is a potential that can trigger conflict and division in society if not able to be addressed wisely. This is where the role of Indonesian people who are able to tolerate the differences in society, so that totality and unity of the nation is maintained. Therefore, character education is very necessary, so that it forms the whole Indonesian people.

According to Zainuddin (2013) Character education is a process of culture and humanity. Character education will lead people to learn with potential they have to become civilized human beings. In the development of character education in schools, educational institutions or schools should be a conducive environment. Schools should be a vehicle for the development of good values or core values.

In its implementation, character education cannot be done instantly, but it should be done gradually and use appropriate strategies based on its conditions. The implementation strategy of character education in the education unit is an integral part of school-based quality improvement of management program implemented in the development, implementation and evaluation of curriculum by educational unit.

According to Kemendiknas (2011: 14), the strategy implementation of character education in educational units can be through integration in the subjects. Each subject contains the content of character values that need to be developed, explored, and linked to the context of daily life. Thus, character learning values are not only on the cognitive level, but also touch on internalization, and real practice in learners' daily life in society. Therefore all learning activities undertaken by educators should not only to develop the knowledge and skills of learners but also can shape the attitude or character as well as the character values attached to the subject.

\section{Material and Methods}

This is a survey study. Thus, in this research implemented observation, interview, dan documentation technic to collect data. The triangulation of this research is method, time and informant. The data analysis technic use reduc- tion-serving-generalization technic by Miles, $\mathrm{Hu}$ berman and Saldana (2014).

The Subject oh this study is primary school teachers Blitar Regency, East Java, Indonesia. they are Social studies teacher who imply character education in the school.

\section{Results and Discussion}

Character building on each individual is influenced by several factors, both internal and external. Every individual is born with certain genetically derived traits (internal factors). In addition to internal factors character formation is also influenced by external factors such as environmental influences and habituation. External factors have considerable influence in shaping the character of each individual. If an individual is in a good environment and learning about something good then he/she will be good also. Vice versa, if the individual is in an environment that is not good and learn about something that is less good he/she will be less good also.

The magnitude of environmental influences (external factors) in shaping the personal character of an individual triggers everyone to learn to be a better individual. This can be done by placing him/herself in a supportive environment. It makes someone to be an individual who is able to behave and socialize well in his/her environment. The good environment is expected to change the character of an individual to be better by implementing good habits so hopefully it keeps going and can be applied in the life.

The school environment is an environment in which a person learns to be an individual who masters knowledge, skills, life skills and social skills. Someone who has received an education is expected to apply the knowledge he/she gets in life while being able to live side by side in society. Thus, education plays a very important role in shaping the personality of an individual who is not only mastering science but also able to live in harmony. The role of education in shaping the character of an individual should be well recognized by the stakeholders of education in this country. Education should not only focus on the mastery of cognitive aspects but also focus on student attitudes and behaviors aspects (affective). The government through the Ministry of Education and Culture has actually divided 
into three domains of learning that have to be mastered by students; they are cognitive, affective and psychomotor domains. But in fact teachers as the spearhead in the field are still focused only on the cognitive aspect. The fact is certainly not in line with what is expected by the government.

Teachers as the spearhead of implementation of education as well as the main character in instilling the characters in every learning that is carried out, should have learning innovation in order good character is embedded for learners maximally. One of the steps that can be done by teachers is to package the learning that create good character is by applying cooperative script strategy. The reason why the strategy can be one of the alternative for teachers in instilling character because the strategy is very activate students and easy applied by teachers.

Cooperative script strategy is part of cooperative learning. Cooperative learning has a special characteristic that is peer group or age group. Tantoanto (2007: 41) argues that the social nature and the use of peer group become the main aspect in cooperative learning. In a cooperative class, students study with small but equal heterogeneous groups, abilities, sex, and should help each other. The advantages of cooperative learning rather than individually are also supported by Wenger's opinion (in Huda, 2013: 49), that is interaction with others can help the individual undergo a more positive learning process than when he is alone.

Komalasari (2010: 63) argues that, "cooperative script is a learning strategy in which students work in pairs, and orally alternately summarize the parts of the material being studied". This opinion is in line with Lambiotte in Huda (2013: 213) "Cooperative Script is one of the learning strategies in which students work in pairs and alternately orally in summarizing the parts of the material being studied. This strategy is aimed to help students to think systematically and to concentrate on the subject matter. Students are also trained to work with each other in a fun atmosphere. Cooperative Script also allows students to find key ideas from great ideas conveyed by teachers.

Cooperative script strategy also contains understanding as peer tutor in which the learn- ing process based on active learning. Some experts believe that one lesson is really mastered only when learners are able to teach other learners. Teaching peers gives opportunities and encourages learners to learn something well, and at the same time they becomes a resource for others (Sarjuli, 2009: 157). In addition, cooperative script is one of the strategies in collaborative learning that is constructivist, training selfreliance, building students' confidence, improving the attitude of cooperation, appreciating, and of course in the knowledge, students can remember the basic ideas that have been summarized so that besides understanding the material, students also memorizing central idea of the material being studied.

Through cooperative strategy, it will form a learning group. In the group, it allows interaction between groups in the form of discussion activities which will form the character of cooperation and appreciate students' opinions. Cooperative scripts strategies can be implemented in a scientific approach considering that in a scientific approach it directs students to observe, ask question, give reason, associate, ans communicate. These five things implicitly appear in the syntax of cooperative script strategy and it can be poured on the learning scenario in the plan learning process.

The application of cooperative script strategy in the implementation of scientific approach is needed because there are still many teachers who do not know about this strategy, especially as a choice of effective strategies in solving problems experienced by teachers. Teachers will be helped in shaping the character of cooperation and appreciating the opinions of the students. So the achievement of the success of learning as mandated by the curriculum is currently pocketed.

Huda (2013: 213) describes the steps of implementing the Cooperative Script learning strategy that is (1) the teacher divides the students into groups in pairs; (2) the teacher divides the discourse or material to read and summarize; (3) teachers and students determine who is first engaged as a speaker and who acts as a listener; (3) the speaker reads the summary as completely as possible by including key ideas into the summary. During the reading process the other students must listen or show uncomplete ideas and help remembering and memorizing the main ide- 
as by relating them to the previous material or with other material; (4) the students exchange roles, originally as speakers converted into listeners and vice versa; (5) teachers and students re-do activities as above with different sub material but still related; (6) teachers and students make a conclusion of subject matter together (7) closing.

The application of cooperative scripts strategy is not difficult to implement. The teacher's knowledge of this strategy can be gained through training on designing the application of the strategy or by reading relevant references. On the required infrastructure, the development of technology creates an increasingly interactive classroom supported with LCD projector and a reading corner that will assist in the delivery of materials. So the need of facilities and infrastructure support can be fulfilled and not a problem to not implement cooperative script strategy.

According to Huda (2013: 214) Cooperative script learning strategy has several advantages such as (a) can grow new ideas or ideas, critical learning power, and develop the spirit of courage in conveying new things that are believed to be true; (b) teach students to trust the teacher and more trust in their own ability to think, seek information from other sources, and learn from other students. (c) encourage students to help solving problems by exposing their ideas verbally and comparing student ideas with other student ideas; (d) help students learn to respect smart students and students who are less intelligent and accept the differences; (e) motivate students who are less clever to be able to express their thoughts; (f) facilitate students to discuss and conduct social interaction; (g) improve the ability to think creatively.

\section{Conclusion}

From the explanation, it can be concluded that the application of learning with cooperative strategy is very effective for implementation of the character of the students. Because the cooperative script strategy supports the social development of learners in which the character will develop well when development of social individual goes well. In addition, learning with cooperative scripts strategy is very easy to be im- plemented by teachers and can train students' thinking and acting skills as an impact of cooperative script strategy.

\section{Suggestion}

This is first studies with the small subject area. So, for the further studies must discover the wider area.

\section{References}

Huda, M. (2013). Model-Model Pengajaran dan Pembelajaran. Yogyakarta: Pustaka Pelajar.

Kemendiknas. (2011). Panduan Pelaksanaan Pendidikan Karakter. Jakarta: Kementrian Pendidikan Nasional.

Komalasari, K. (2010). Pembelajaran Kontekstual Konsep dan Aplikasi. Jakarta: Rafika Aditama.

Miles, M.B., Huberman, A.M., \& Saldana, J. (2014). Qualitative Data Analysis: A Methods Sourcebook. Third Edition. SAGE Publication Asia-Pacific Pte. Ltd. Singapore.

Sarjuli. (2009). Active Learning: 101 Strategi Pembelajaran Aktif. Yogyakarta: Pustaka Insan Madani.

Trianto. (2007). Model-Model Pembelajaran Inovatif Berorientasi Konstruktivistik. Jakarta: Prestasi Pustaka.

Zainuddin, HM. (2010). Membentuk Karakter Anak melalui Pembelajaran IPS. Malang: Penerbit Universitas Negeri Malang (UM Press). 